\title{
iaspm@journal
}

ISSN 2079-3871

\section{REVIEW I Blue Rhythm Fantasy: Big Band Jazz Arranging in the Swing Era \\ John Wrigg/e}

Urbana: University of Illinois Press, 2016

ISBN: 9780252082269 (PB)

\author{
Jeremiah Spillane \\ Goldsmiths, University of London \\ jeremiah.spillane@gold.ac.uk
}

The 1930s to mid-1940s, the Swing Era, was a period where jazz moved to the forefront of American popular culture. This period is characterized by the big bands and the leaders who brought them to prominence: Ellington, Lunceford, Calloway, Krupa, and Goodman among others. Yet no less central to the story of the Swing Era, though largely omitted from the histories, is the story of the arranger. This omission, often resulting from the view of arranging as being purely commercial and functional rather than a legitimate creative endeavour, is a problem that is central to this thesis. Accordingly then, this publication is a welcome addition to the literature on this significant period and sheds some long overdue light on lesser-known figures, their art form, and their place in popular music history.

Author John Wriggle, an arranger, composer, and musicologist - having taught at the City University of New York, Rutgers University, and Boston University, and transcribed period jazz repertoire for Jazz at the Lincoln Centre - is well placed to navigate the largely hidden history of the commerce and creative practice behind some of the most recognisable big band arrangements of the Swing Era. In doing so, this work aims to redress the lack of inclusion, or at best "hazy presence" as Wriggle refers to it, of arrangers in jazz history (1).

Wriggle's text takes as its primary focus the work of freelance arranger Chappie Willet (1907-76) and his Broadway Music Clinic. In Gunther Schuller's seminal text on the Swing Era, Chappie Willet features only twice and, while his work is briefly discussed in a positive light, his presence is fleeting and obscured under a broader discussion of Louis Armstrong and Gene Krupa (Schuller 1989: 193, 724-725). More recent histories of jazz

IASPM@Journal vol.7 no.2 (2017)

Journal of the International Association for the Study of Popular Music

ISSN 2079-3871 I DOI 10.5429/2079-3871(2017)v7i2.13en I www.iaspmjournal.net 
do not feature any mention of Willet, (see for example Gioia 1997; Cooke 1998; DeVeaux \& Giddins 2009; Shipton 2013). While a canonical figure Willet is not, Wriggle suggests his work "generally met contemporary expectations of genre and style and demonstrates the cultural powers of arranging within the Swing Era big band idiom" (5). For this alone, Wriggle's work is a worthwhile project, focusing scholarly attention on those who have thus far been featured largely, if at all, in the footnotes of more recognisable, canonical names.

From the outset, Wriggle makes clear that his work is neither a definitive history, nor a how-to guide on arranging, rather he states his aims are to "explore some of the motivations and ideologies behind the different arranging strategies that defined Swing Era music and to consider the broader legacy of arrangers in American culture" (2). Part biography, part analytical work, and part cultural history, Wriggle's multifaceted approach does much to strengthen the study as a whole.

Methodologically, Wriggle combines a number of approaches, including testimonies and oral histories from arrangers active during the Swing Era, to comparative analytical discussion of surviving manuscripts held in archival collections (6). Additionally, the author draws regularly on weekly black newspapers such as the New York Amsterdam News and the Chicago Defender (as an alternative to white news sources), avoiding some of the problems encountered elsewhere in jazz research (Porter 1988: 199).

The book is divided into three sections. The initial three chapters deal with the political, economic, and professional contexts of arrangers and provide a good overview of the commerce of Willet's Boston Music Clinic, including discussion of the other staff and their roles (30-33).

The second section, encompassing chapters four, five, and six, explores the musical techniques and methods employed and favoured by popular music arrangers in the Swing Era. Here, Wriggle draws on both oral and written accounts of arrangers to highlight what sources they drew upon to inform their practice. Wriggle further highlights how historical changes affected the theory and practice of the music. Chapter five addresses the influence of theatrical orchestration on popular music and includes an interesting discussion of chromatic and whole-tone devices in relation to musical modernism, episodic form and the influence of concert music on popular music (94-95). This discussion further includes the influence of European concert composers, such as Debussy. Chapter six highlights the signification of black cultural history, harking back to performance characteristics of ragtime fused with the more contemporary (Swing Era) approaches to formal orchestration and arrangement.

The final section, encompassing chapters seven, eight, and nine, is really the standout and uniquely interesting section of this work. Chapter eight features a discussion of ballads and novelty songs that were in vogue during the period. Wriggle presents a particularly interesting case study of the comedy-dance trio, the Three Chocolateers and their novelty number, "The Hicky Ricky". This case study explores

"Willet's relationship with 'The Hicky Ricky' and its performers demonstrating multiple facets of the Swing Era music business. A tracing of the song's origins, publicity, and reception reveals not only trends in popular music arranging, composing, marketing, and performance, but also the racial segregation of American entertainment, the business structures that maintained those barriers, and the available options of response for black artists" (152). 
Chapter nine, following earlier discussion of arranging methods, brings us back to an analytical examination of Willet's instrumental dance music and the representation of the "exotic" (172-173). This particular case study focuses on Willet's work, "Blue Rhythm Fantasy", which presents itself as a rich source of discussion here. "Blue Rhythm Fantasy" highlights Willet's style and influences but also, through the various versions of the work, identifies the commercial demands encountered by the arranger. As the author elaborates,

"Willet's musical influences and personal style are highlighted in the song's combination of whole-tone voicings and half-step chromaticism, while various adaptations reflect the differing requirements of his clients. In addition to documentation in period audio recordings and archival manuscripts, 'Fantasy' also carries a modest reception history that parallels broader trends in jazz historiography" (182).

A number of different "stock" and "special" arrangements of "Fantasy" provide material for Wriggle to construct and examine this worthwhile case study, proposing a number of different models and influences for "Blue Rhythm Fantasy" as he closes out his work (184185).

There is much to celebrate in this research. In avoiding the hagiographic focus of much historiographic work on jazz, Wriggle has done well to both elevate the art of arranging and further illuminate the workings of the music industry in New York during the Swing Era (43). Wriggle has provided extensive detail on the length and breadth of the commerce; from the clubs' takings, to the arranger and the dancer fees, and weaving in the views of performers on the minutiae of the musicians working lives, providing the reader with detailed overview of the working practices of the time (43). Comparisons on earnings from touring versus residencies are highlighted (see the Ellington example on page 43), plus the benefits of performing at New York clubs which might provide enhanced promotional opportunities through, for example, live radio broadcasts.

Quite a lot of musical detail has been included through the provision of scored examples, including a number of reductions by the author, and Wriggle navigates and unpacks the musical figures well. As a result, I would expect this work to be read comfortably by specialists and non-specialists alike. Wriggle's broad approach has made this work valuable to those looking to learn a little more about arranging and its history, as well as being of use to those more specialized in the field, by providing an array of interesting examples to highlight the stylistic features of the period in the discussions.

While Wriggle's attention to detail is to be commended, some sections do at times (for example in chapter 3) feel simply like reference material on dates, prices, and places. While well-sourced and structured these sections can, with the exception of the occasional firsthand accounts such as that of Clyde Bernhardt's description of the Ubanggi club (57), leave the reader somewhat drifting.

In conclusion, Wriggle's work is well-researched, well-structured, and gives a great overview of the Swing Era career of Chappie Willet, which is further complimented by a thorough examination of his stylistic "idiolect" (108-126). The biographical outline of this lesser-known figure accompanied by the detailed overview of his commercial endeavours, in addition to the excellent analytical discussion of the arrangements provided here (182191), make this an essential read for those interested in jazz studies and, in particular, the Swing Era. It is, however, the detailed impression of the wider popular music scene and the working interactions between venues, bands, and arrangers discussed here that will 
ensure this publication will be of interest to those researching the history of popular music more broadly.

\section{References}

Cooke, M. 1998. Jazz. London: Thames \& Hudson.

DeVeaux, S. and Giddins, G. 2009. Jazz. New York: W.W. Norton.

Gioia, T. 1997. The History of Jazz. New York: Oxford University Press.

Porter, L. 1988. Some Problems in Jazz Research. Black Music Research Journal 8 (2): 195-206. Schuller, G. 1989. The Swing Era (Vol. 2) The Development of Jazz 1930 - 1945, New York and Oxford: Oxford University Press

Shipton, A. 2013. A New History of Jazz. New York, NY: Continuum. 